\title{
Different toll-like receptor expression patterns in progression toward cancer
}

\author{
Lauri Jouhi $^{1{ }^{* \dagger}}$, Suvi Renkonen ${ }^{1 \dagger}$, Timo Atula ${ }^{1}$, Antti Mäkitie ${ }^{1}$, Caj Haglund ${ }^{2}$ and Jaana Hagström ${ }^{3}$ \\ ${ }^{1}$ Department of Otorhinolaryngology, University of Helsinki and Helsinki University Hospital, Helsinki, Finland \\ ${ }^{2}$ Department of Surgery, University of Helsinki and Helsinki University Hospital, Helsinki, Finland \\ ${ }^{3}$ Department of Pathology and Oral Pathology, Haartman Institute, Institute of Dentistry and HusLab, University of Helsinki and Helsinki University Hospital, \\ Helsinki, Finland \\ ${ }^{*}$ Correspondence: lauri.jouhi@helsinki.fi \\ ${ }^{+}$Lauri Jouhi and Suvi Renkonen have contributed equally to this work. \\ Edited by: \\ Catherine Sautes-Fridman, UMRS 1138, France \\ Reviewed by: \\ Fabian Benencia, Ohio University, USA \\ Catherine Sautes-Fridman, UMRS 1138, France
}

Keywords: innate immunity, carcinoma, pre-malignant lesions, pattern-recognizing receptors, immunohistochemistry

\section{TLRs IN HEALTHY TISSUE}

Pattern recognition forms the basis of the innate immune system, allowing it to maintain systemic homeostasis by rejecting harmful molecular structures. Immune cells as well as epithelial cells located near the host-environment boundary, express pattern-recognizing receptors, the activation of which launches cascades leading to immune response and apoptosis $(1,2)$. Human toll-like receptors (TLRs) 1-10, a family of trans-membrane receptor proteins comprising one type of pattern-recognizing receptors, participate in these immunological processes. In healthy immune cells and epithelial cells, TLR 1, 2, 4, 5, 6, and 10 are usually expressed on the cell surface, whereas TLR 3, 7, 8, and 9 are mainly expressed on the surfaces of endosomes, lysosomes, and endoplasmic reticulum (3). Microbial molecular structures activating patternrecognizing receptors are called pathogenassociated molecular patterns (PAMPs) $(1,2)$. Besides exogenous structures, also endogenous molecules, released, for example, from inflamed or damaged tissues, can activate pattern-recognizing receptors and are called danger- or damage-associated molecular patterns (DAMPs) $(4,5)$. Ligands binding to TLR lead to the activation of several intracellular signaling pathways, activating, for instance, nuclear transcription factors that initiate host defense functions via secretion of co-stimulatory factors and cytokines (6). TLR activation leads also to regulation of gene expression, cell proliferation, differentiation, mitosis, cell-cycle regulation, and apoptosis (7).

\section{TLRS IN ABNORMAL CONDITIONS}

In healthy tissues, TLRs participate in the initiation of inflammatory defense mechanisms, but under abnormal conditions their activation may lead to the process of inflammation becoming chronic. Chronic inflammation is a favorable environment for tumor initiation and progression in multiple organs, including the cervix, stomach, colon, and liver (8-11). In several pre-malignant and malignant conditions, TLRs have been overexpressed (1215). TLRs can activate immunity affecting proteins like nitric oxide synthase 2 and cyclooxygenase 2, leading to increased malignant potential of cancer cells (12, 16). TLRs can also up-regulate immunosuppressive agents like vascular endothelial growth factor, and transforming growth factor beta within the tumor microenvironment and thus modulate immunity. These modifications can lead to increased angiogenic and metastatic potential of tumors (17). The role of TLRs in cancer is, however, controversial. Activation of TLRs can also lead to tumor inhibition (18-21). The role of TLRs in cancer is therefore ambiguous, as they can on the one hand mediate signaling leading to inhibition of apoptosis and disrupted cell proliferation, and on the other hand, activate immunologic responses against cancer.

Patterns of TLRs expression in terms of frequencies and their subcellular locations are different in cancer microenvironment and in healthy tissue. Here, we discuss the observations of TLR expression patterns in normal, pre-malignant, and carcinoma tissues.

\section{TRANSFORMATION OF TLR EXPRESSION IN CANCEROUS PROGRESSION}

Under normal circumstances, TLR 2, 4, and 5 are expressed principally on the membrane. During the transformation toward dysplasia, their expression becomes stronger and more cytoplasmic.

The transforming expression pattern has been shown, for example, in the situation of TLR 5 and normal esophageal epithelium transforming toward cancer. In non-dysplastic esophageal epithelium, TLR 5 expression is located exclusively in basolateral plasma membrane and basal cytoplasm (15). During the progression toward dysplasia, the polarity of TLR 5 expression ceases and expression becomes more diffuse. In esophageal adenocarcinoma, the intensity of TLR 5 staining is weaker, when compared to that of columnar epithelial dysplasia, but it follows identical diffuse staining pattern (15). In oral epithelium, TLR 5 expression is already cytoplasmic in healthy tissue but its expression in oral epithelial cancer has been stronger than in healthy epithelium (22).

The phenomenon of stronger and more diffuse TLR expression has appeared also in other TLR subtypes and cancer types. Healthy colon mucosa expresses only 
minor TLR 4 positivity. In colon dysplasia and adenocarcinoma, TLR 4 expression becomes more evident and is strong and diffuse both in cytoplasm and on membranes (23). TLR 2, 4, and 5 follow the same diffuse cytoplasmic pattern in colon adenocarcinoma, TLR 2 and 4 in gastric columnar epithelial dysplasia, and adenocarcinoma, and TLR 2 and 4 in follicular thyroid carcinoma (24-26).

In colon and gastric columnar epithelial dysplasia, the level of a TLR antagonist, toll-interacting protein (TOLLIP) decreases, whereas TLR expression transforms toward being more diffuse and cytoplasmic. The normal TOLLIP pathway leads to the degradation of excess TLRs. Disruption of the TOLLIP pathway results in excess and altered TLR expression (24, 25).

When DAMPs are bound to plasma membrane or as the cell loses its plasma membrane integrity, and they are released to extracellular matrix, the immune response is initiated $(27,28)$. DAMPs are able to interact with the immune system to cause tumor suppression, but on the other hand, they can also contribute to cancer progression (29).

DAMPs are confined to the cytosol and nucleus of healthy cells (28). In cancer cells, however, they can be overexpressed, and their intracellular localization can become altered. For example, in cancer, the normally nuclear DAMP-molecule HMGB1 is overexpressed in cytoplasm $(30,31)$. TLRs 2, 4, and 9 are target receptors for HMGB1 and their activation can launch cascades leading, for instance, to induction of pro-inflammatory cytokines, promotion of angiogenesis, and stimulation of cell migration via downstream intracellular pathways (32). Previously, TLRs that are overexpressed in cytoplasm are suggested to function as a reserve for greater redistribution to the plasma membrane, where they are activated by their extracellular ligands, such as bacteria (24, 25). We could, however, hypothesize that TLRs that are overexpressed and relocated to the cytoplasm in cancer might also be activated in the cytoplasm by their DAMP-ligands, which are equally overexpressed and relocated in to the cytoplasm. This kind of abnormal and uninterrupted intracellular TLR activation could lead to tumor progression in addition to normal inflammatory cascades, although the role of cytoplasmic TLRs needs further study.

\section{REFERENCES}

1. Janeway CA Jr. Approaching the asymptote? Evolution and revolution in immunology. Cold Spring Harb Symp Quant Biol (1989) 54(Pt 1):1-13. doi:10.1101/SQB.1989.054.01.003

2. Medzhitov R, Janeway CA Jr. Innate immunity: the virtues of a nonclonal system of recognition. Cell (1997) 91(3):295-8. doi:10.1016/S0092-8674(00) 80412-2

3. Kumar H, Kawai T, Akira S. Toll-like receptors and innate immunity. Biochem Biophys Res Commun (2009) 388(4):621-5. doi:10.1016/j.bbrc.2009.08. 062

4. Matzinger P. Tolerance, danger, and the extended family. Annu Rev Immunol (1994) 12:991-1045. doi:10.1146/annurev.immunol.12.1.991

5. Matzinger P. The danger model: a renewed sense of self. Science (2002) 296(5566):301-5. doi:10.1126/ science. 1071059

6. Kawai T, Akira S. Pathogen recognition with toll-like receptors. Curr Opin Immunol (2005) 17(4):338-44. doi:10.1016/j.coi.2005.02.007

7. Basith S, Manavalan B, Yoo TH, Kim SG, Choi S. Roles of toll-like receptors in cancer: a doubleedged sword for defense and offense. Arch Pharm Res (2012) 35(8):1297-316. doi:10.1007/s12272012-0802-7

8. Zur Hausen H. Condylomata acuminata and human genital cancer. Cancer Res (1976) 36(2 Pt 2):794.

9. Parsonnet J, Friedman GD, Vandersteen DP, Chang Y, Vogelman JH, Orentreich N, et al. Helicobacter pylori infection and the risk of gastric carcinoma. N Engl J Med (1991) 325(16):1127-31. doi:10.1056/NEJM199110173251603

10. Bargen JA. Chronic ulcerative colitis associated with malignant disease. 1928. Dis Colon Rectum (1994) 37(7):727-30. doi:10.1007/BF02054420

11. Beasley RP, Hwang LY, Lin CC, Chien CS. Hepatocellular carcinoma and hepatitis B virus. A prospective study of 22707 men in Taiwan. Lancet (1981) 2(8256):1129-33. doi:10.1016/ S0140-6736(81)90585-7

12. Huang B, Zhao J, Li H, He KL, Chen Y, Chen $\mathrm{SH}$, et al. Toll-like receptors on tumor cells facilitate evasion of immune surveillance. Cancer Res (2005) 65(12):5009-14. doi:10.1158/0008-5472. CAN-05-0784

13. Schmausser B, Andrulis M, Endrich S, MullerHermelink HK, Eck M. Toll-like receptors TLR4, TLR5 and TLR9 on gastric carcinoma cells: an implication for interaction with Helicobacter pylori. Int J Med Microbiol (2005) 295(3):179-85. doi:10.1016/j.ijmm.2005.02.009

14. Droemann D, Albrecht D, Gerdes J, Ulmer AJ, Branscheid D, Vollmer E, et al. Human lung cancer cells express functionally active toll-like receptor 9. Respir Res (2005) 6:1. doi:10.1186/1465-99216-68

15. Helminen O, Huhta H, Takala H, Lehenkari PP, Saarnio J, Kauppila JH, et al. Increased toll-like receptor 5 expression indicates esophageal columnar dysplasia. Virchows Arch (2014) 464(1):11-8. doi:10.1007/s00428-013-1505-2
16. Fukata M, Chen A, Vamadevan AS, Cohen J, Breglio K, Krishnareddy S, et al. Toll-like receptor-4 promotes the development of colitisassociated colorectal tumors. Gastroenterology (2007) 133(6):1869-81. doi:10.1053/j.gastro.2007. 09.008

17. He W, Liu Q, Wang L, Chen W, Li N, Cao X. TLR4 signaling promotes immune escape of human lung cancer cells by inducing immunosuppressive cytokines and apoptosis resistance. Mol Immunol (2007) 44(11):2850-9. doi:10.1016/j.molimm. 2007.01.022

18. Okamoto M, Oshikawa T, Tano T, Ohe G, Furuichi $\mathrm{S}$, Nishikawa $\mathrm{H}$, et al. Involvement of toll-like receptor 4 signaling in interferon-gamma production and antitumor effect by streptococcal agent OK-432. J Natl Cancer Inst (2003) 95(4):316-26. doi:10.1093/jnci/95.4.316

19. Lowe EL, Crother TR, Rabizadeh S, Hu B, Wang $\mathrm{H}$, Chen S, et al. Toll-like receptor 2 signaling protects mice from tumor development in a mouse model of colitis-induced cancer. PLoS One (2010) 5(9):e13027. doi:10.1371/journal.pone.0013027

20. Matijevic T, Marjanovic M, Pavelic J. Functionally active toll-like receptor 3 on human primary and metastatic cancer cells. Scand J Immunol (2009) 70(1):18-24. doi:10.1111/j.13653083.2009.02262.x

21. Bauer AK, Dixon D, DeGraff LM, Cho HY, Walker CR, Malkinson AM, et al. Toll-like receptor 4 in butylated hydroxytoluene-induced mouse pulmonary inflammation and tumorigenesis. J Natl Cancer Inst (2005) 97(23):1778-81. doi:10.1093/ jnci/dji403

22. Kauppila JH, Mattila AE, Karttunen TJ, Salo T. Toll-like receptor 5 (TLR5) expression is a novel predictive marker for recurrence and survival in squamous cell carcinoma of the tongue. $\mathrm{Br} J \mathrm{Can}$ cer (2013) 108(3):638-43. doi:10.1038/bjc.2012. 589

23. Wang EL, Qian ZR, Nakasono M, Tanahashi T, Yoshimoto K, Bando Y, et al. High expression of toll-like receptor 4/myeloid differentiation factor 88 signals correlates with poor prognosis in colorectal cancer. Br J Cancer (2010) 102(5):908-15. doi:10.1038/sj.bjc.6605558

24. Pimentel-Nunes P, Goncalves N, Boal-Carvalho I, Afonso L, Lopes P, Roncon-Albuquerque R Jr, et al. Decreased toll-interacting protein and peroxisome proliferator-activated receptor are associated with increased expression of toll-like receptors in colon carcinogenesis. J Clin Pathol (2012) 65(4):302-8. doi:10.1136/jclinpath-2011-200567

25. Pimentel-Nunes P, Goncalves N, Boal-Carvalho I, Afonso L, Lopes P, Roncon-Albuquerque R Jr, et al. Helicobacter pylori induces increased expression of toll-like receptors and decreased toll-interacting protein in gastric mucosa that persists throughout gastric carcinogenesis. Helicobacter (2013) 18(1):22-32. doi:10.1111/hel.12008

26. Hagstrom J, Heikkila A, Siironen P, Louhimo J, Heiskanen I, Maenpaa H, et al. TLR-4 expression and decrease in chronic inflammation: indicators of aggressive follicular thyroid carcinoma. J Clin Pathol (2012) 65(4):333-8. doi:10.1136/jclinpath2011-200402

27. Obeid M, Tesniere A, Ghiringhelli F, Fimia GM, Apetoh L, Perfettini JL, et al. Calreticulin exposure dictates the immunogenicity of cancer cell 
death. Nat Med (2007) 13(1):54-61. doi:10.1038/ $\mathrm{nm} 1523$

28. Shi Y, Zheng W, Rock KL. Cell injury releases endogenous adjuvants that stimulate cytotoxic $\mathrm{T}$ cell responses. Proc Natl Acad Sci U S A (2000) 97(26):14590-5. doi:10.1073/pnas.260497597

29. Krysko O, Love Aaes T, Bachert C, Vandenabeele P, Krysko DV. Many faces of DAMPs in cancer therapy. Cell Death Dis (2013) 4:e631. doi:10.1038/ cddis. 2013.156

30. Castellani P, Balza E, Rubartelli A. Inflammation, DAMPs, tumor development, and progression: a vicious circle orchestrated by redox signaling. Antioxid Redox Signal (2014) 20(7):1086-97. doi: 10.1089/ars.2012.5164

31. Jube S, Rivera ZS, Bianchi ME, Powers A, Wang E, Pagano I, et al. Cancer cell secretion of the
DAMP protein HMGB1 supports progression in malignant mesothelioma. Cancer Res (2012) 72(13):3290-301. doi:10.1158/0008-5472.CAN11-3481

32. Kang R, Zhang Q, Zeh HJ III, Lotze MT, Tang D. HMGB1 in cancer: good, bad, or both? Clin Cancer Res (2013) 19(15):4046-57. doi:10.1158/ 1078-0432.CCR-13-0495

Conflict of Interest Statement: The authors declare that the research was conducted in the absence of any commercial or financial relationships that could be construed as a potential conflict of interest.

Received: 20 August 2014; accepted: 29 November 2014; published online: 15 December 2014.
Citation: Jouhi L, Renkonen S, Atula T, Mäkitie A, Haglund C and Hagström J (2014) Different toll-like receptor expression patterns in progression toward cancer. Front. Immunol. 5:638. doi: 10.3389/fimmu.2014.00638 This article was submitted to Tumor Immunity, a section of the journal Frontiers in Immunology.

Copyright () 2014 Jouhi, Renkonen, Atula, Mäkitie, Haglund and Hagström. This is an open-access article distributed under the terms of the Creative Commons Attribution License (CC BY). The use, distribution or reproduction in other forums is permitted, provided the original author(s) or licensor are credited and that the original publication in this journal is cited, in accordance with accepted academic practice. No use, distribution or reproduction is permitted which does not comply with these terms. 